\title{
Unexpected effects of starfish grazing on sandflat communities following an outbreak
}

\author{
D. Pillay*, G. M. Branch, A. Steyn \\ Zoology Department, Marine Research Institute, University of Cape Town, PB X3, Rondebosch 7701, South Africa
}

\begin{abstract}
Starfish are significant determinants of community structure in marine ecosystems. The starfish Parvulastra (Patiriella) exigua is normally found on intertidal rocky shores. We examined a major outbreak of this species in Langebaan Lagoon, a marine embayment on the west coast of South Africa, and the only known soft-sediment ecosystem where $P$. exigua flourishes. We document this outbreak and describe subsequent field caging experiments testing the influence of this starfish on soft-sediment community structure. Grazing by $P$. exigua resulted in a reduction in microalgal biomass that was linearly related to starfish density, but it promoted bacterial density. Macrofaunal communities at intermediate densities of $P$. exigua were different and more diverse to those at high and low starfish densities, with Shannon-Wiener and Fischer's $\alpha$ indices peaking at intermediate density of $P$. exigua. It is possible that $P$. exigua at intermediate densities promotes co-existence of macrofauna by reducing the competitive edge held by dominant species. However, this effect may also be due to the balance between (1) negative effects of microalgal depletion and incidental grazing on invertebrate recruits at high densities of $P$. exigua, and (2) enhancement of bacteria by $P$. exigua leading to increased biofilm coverage on the sediment, which promotes macrofaunal recruit diversity in soft sediments. We suggest a need for caution when citing results from marine soft sediments as evidence for the intermediate disturbance hypothesis without knowledge of the promotive and inhibitory effects of the target organism.
\end{abstract}

KEY WORDS: Population outbreak $\cdot$ Disturbance $\cdot$ Recruitment $\cdot$ Biofilms $\cdot$ Macrofauna $\cdot$ Promotive effects $\cdot$ Inhibitory effects

Resale or republication not permitted without written consent of the publisher

\section{INTRODUCTION}

Population explosions of marine organisms are common phenomena across the globe, and have been related to natural ecosystem variability, climate change or anthropogenic influences (Moran et al. 1988, Brodie et al. 2005, Xian et al. 2005, Purcell et al. 2007, Uthicke et al. 2009). Among anthropogenic causes, the removal of predatory fish by coastal fisheries has been linked to population explosions of jellyfish, due to reduced predation pressure (Xian et al. 2005, Purcell et al. 2007). Eutrophication of nearshore marine ecosystems and associated increases in food availability have also been suggested as a causal mechanism, and has for example, been linked to out- breaks of the coral-eating crown-of-thorns starfish Acanthaster planci (Brodie et al. 2005).

Whatever the causes, population explosions can have major cascading effects on community structure. Outbreaks of sea-urchins can completely alter subtidal benthic communities, often turning lush kelp forests into barren fields of encrusting species (Elner \& Vadas 1990). Population explosions of jellyfish can also modify pelagic food webs by consuming fish, eggs and larvae, thereby negatively affecting fish abundance (Xian et al. 2005). Alternatively, jellyfish blooms may outcompete other pelagic organisms by diminishing organic matter availability (Brodeur et al. 2002).

Here we report on an outbreak of the grazing starfish Parvulastra (= Patiriella) exigua in Langebaan 
Lagoon on the west coast of South Africa between 1975 and 1983. We also present results from a manipulative field experiment testing the effects of this starfish on community structure at more natural densities following the outbreak. $P$. exigua is relatively small $(5 \mathrm{~cm}$ in diameter) and is very common on intertidal rocky shores in South Africa and Australia (Branch \& Branch 1980, Jackson et al. 2009). It rarely occurs in intertidal lagoonal sandflats or other soft-sediment ecosystems, although the population in Langebaan Lagoon has been established there for at least the last 50 yr (Day 1959).

Starfish are important structuring agents of invertebrate communities in rocky and coral reef ecosystems. Paine (1974) identified the keystone role of the starfish Pisaster ochraceus in intertidal rocky communities, demonstrating that its predation on mussels reduces their competitive edge, leading to increased diversity of co-occurring rock-occupying species. The coraleating crown-of-thorns starfish Acanthaster planci is a major determinant of coral reef community structure in the Indo-Pacific notorious for its devastating effects, and is regarded as a greater threat to coral reefs than any anthropogenic impact (Moran et al. 1988).

Studies examining the effects of starfish grazing in soft sediments are rare (e.g. Scheibling 1980), and comparatively more is known of their effects as predators (e.g. McClintock \& Lawrence 1985). Grazing by other invertebrates is well recognised as a significant factor structuring marine communities in both rocky and sedimentary ecosystems (Hawkins \& Hartnoll 1983, Morrisey 1988, Anderson \& Underwood 1997. Silliman \& Bertness 2002, Jackson et al. 2009). Many studies have reported intricate effects involving positive or negative effects depending on grazer density and species (Hargrave 1970, Flint \& Goldman 1975, Morrisey 1988) with both direct and indirect consequences (Anderson 1999). Grazing may affect resource availability and habitat heterogeneity (Jackson et al. 2009), rates of succession and recruitment (Levinton \& Stewart 1982) and the abundance and composition of algal and invertebrate assemblages (Morrisey 1988, Keleher et al. 2003).

Until recently, grazing by starfish has not been considered a major determinant of algal and invertebrate community structure on rocky shores, where limpets and other grazing molluscs have generally been shown to be of primary importance (Hawkins \& Hartnoll 1983, Jackson et al. 2009). However, Jackson et al. (2009) have noted that starfish grazing on rocky communities may be underestimated, particularly in terms of its effects on microalgal biofilms. Starfish grazing on soft sediments may additionally influence soft-sediment communities by modifying substrate characteristicsand thereby influencing recruitment patterns, a factor likely to be of less significance on rocky substrata (Peterson 1979, Wilson 1991, Pillay et al. 2007).

There are 2 major types of starfish-sediment interactions that could potentially structure communities, viz. physical sediment disturbance (bioturbation) and alterations to sediment biogeochemistry. Bioturbation by other grazers is known to affect sediment stability and erosion of surface microalgae (Anderson 2001, Anderson et al. 2002, Orvain et al. 2004), as well as the recruitment of juvenile invertebrates (Hunt et al. 1987). Other soft-sediment macrofaunal species have been reported to affect dissolved oxygen levels, chemical composition and fluxes and microbial biofilm characteristics (Widdicombe \& Austen 1998, Pillay et al. 2007).

In view of the strong effects induced by grazers on community structure: the aims of this paper were to (1) document the outbreak of Parvulastra exigua in Langebaan Lagoon, and (2) experimentally investigate the effects of grazing by $P$. exigua on benthic microalgae, bacteria and macrofaunal community structure following the starfish outbreak in 1985.

\section{MATERIALS AND METHODS}

Parvulastra exigua density was monitored roughly biennially between 1972 and 2007 at Klein Oesterval in Langebaan Lagoon (located between $33^{\circ} 1^{\prime} 27^{\prime \prime} \mathrm{S}$, $18^{\circ} 07^{\prime} 37^{\prime \prime} \mathrm{E}$ and $\left.33^{\circ} 03^{\prime} 54^{\prime \prime} \mathrm{S}, 17^{\circ} 58^{\prime} 07^{\prime \prime} \mathrm{E}\right)$, on the west coast of South Africa. The lagoon is marine-dominated with virtually no freshwater input (Day 1959). Three replicate transects were run down the shore and sampling undertaken in 10 equally-spaced $0.25 \mathrm{~m}^{2}$ quadrats from the mean high water spring (MHWS) to the mean low water spring (MLWS) marks in which $P$. exigua were counted. Transects spanned beds of the seagrass Zostera capensis and adjacent bare sand.

Experimental design. Field experiments involving exclusion and inclusion cages were also undertaken at Klein Oesterval, Langebaan Lagoon in November 1985, after the outbreak of Parvulastra exigua, as densities of this starfish returned to more natural levels (see Fig. 1). This experiment was aimed at testing the effects of $P$. exigua density on abundance of microalgae and bacteria, and on macrofaunal community structure following the outbreak. The experiment was conducted in the mid-intertidal shore in an area where $P$. exigua was common, reaching (at that time) densities of 10 to 20 ind. $\mathrm{m}^{-2}$. Four treatments were employed: control cages excluding $P$. exigua, and cages including $P$. exigua $\left(1\right.$ per cage $=10$ ind. $\mathrm{m}^{-2}$ i.e. background density at that time, $\mathrm{N}_{i} 2$ or 4 per cage, i.e. $2 \mathrm{~N}$ or $4 \mathrm{~N}$ ). All treatments had 3 replicates. Cage 
controls, such as partial cages, were not practical as starfish would have escaped from them (Jackson et al. 2009), thereby confounding the interpretation of cage effects.

Cages were cylindrical $($ diameter $=35.6 \mathrm{~cm}$, area $=$ $0.1 \mathrm{~m}^{2}$ ) and made of $2 \mathrm{~mm}$ mesh-size plastic netting that covered the tops and sides. The cages were buried $10 \mathrm{~cm}$ deep into the sediment and protruded $10 \mathrm{~cm}$ above the sediment surface. Sediment cores were collected for chlorophyll a ( $\mathrm{chl} \mathrm{a}$ ) and bacteria, 1 and 2 mo after cages were installed, and 2 mo after cage installation for macrofauna.

Sample collection and analyses. Single sediment cores were collected from each cage for macrofauna, bacteria and chl a. Macrofaunal cores (internal diameter $=30 \mathrm{~cm}$, area $=0.07 \mathrm{~m}^{2}$, depth $=20 \mathrm{~cm}$ ) were preserved with phloxine-stained formalin (4\% final concentration) and sieved through a $500 \mu \mathrm{m}$ sieve to remove macrofauna. Organisms were viewed under a dissecting microscope and identified to the lowest possible taxonomic level, and their density expressed as counts $\mathrm{m}^{-2}$. The total wet-weight biomass $(\mathrm{g})$ of each sample was measured and scaled up to $\mathrm{g} \mathrm{m}^{-2}$.

For bacteria, a $1 \mathrm{~g}$ subsample from each sediment core (diameter $=2 \mathrm{~cm}$, depth $=1 \mathrm{~cm}$ ) was diluted with $100 \mathrm{ml}$ sterile artificial seawater, preserved with $5 \%$ formaldehyde and stained with acridine orange for $3 \mathrm{~min}$. A subsample of the liquid fraction was filtered on black membrane filters (diameter $=47 \mathrm{~mm}$, pore size $=0.45 \mu \mathrm{m}$ ), and viewed under oil immersion (magnification $=100 \times)$ with incident UV light. Twenty fields of view were counted for each filter. Data are expressed as counts $\mathrm{g}^{-1}$ of sediment (dry wt).

For microalgal biomass, chl a was extracted from sediment cores (collected at midday, diameter $=2 \mathrm{~cm}$, depth $=1 \mathrm{~cm}$ ) by grinding the sample in $90 \%$ acetone, followed by centrifugation $(10000 \times g, 60 \mathrm{~s})$. Chl a levels in the supernatant were then measured spectrophotometrically according to Lorenzen (1967). Data are expressed as $\mu \mathrm{g} \mathrm{g}^{-1}$ of sediment (dry wt).

Statistical analyses. All multivariate analyses were performed using PRIMER v 6 (Plymouth Routines in Multivariate Ecological Research) (Clarke \& Gorley 2006) based on untransformed and unstandardised abundance data. Non-metric multidimensional scaling (MDS) and cluster analysis were used to assess differences in macrofaunal assemblages among treatments, based on resemblance matrices generated from BrayCurtis similarities. ANOSIM (analysis of similarity) tested for statistical differences among treatments, with pairwise tests highlighting statistically significant inter-treatment differences. SIMPER identified the dominant macrofaunal taxa that characterised treatments. The DIVERSE function was used to calculate the following community parameters for each treat- ment: total abundance of macrofauna, species richness (expressed as total numbers of species per sample, S) and community diversity (Shannon Wiener to the base e, and Fischer's $\alpha$ index). Cumulative dominance plots, based on mean abundance data for each treatment, were used to evaluate differences in dominance and diversity among treatments.

Univariate statistical tests were performed using SPSS v 16. Two-way analysis of variance (ANOVA) tested for the effects of treatment and time, and the interaction between the 2 variables, on bacterial and microalgal levels. One-way ANOVA was used to test for differences in macrofaunal community parameters among treatments, with post-hoc Tukey tests for intertreatment comparisons. The curve estimation function was used to determine the best relationship between Parvulastra exigua density and levels of bacteria and chl $a$, as well as macrofaunal community parameters. Normality and homogeneity of variance required for parametric testing were assessed using the Kolmogorov-Smirnov and Levene's tests respectively. In instances where these assumptions were not met, data were transformed $(\log [x+1]$ or square root).

\section{RESULTS}

\section{Temporal variations in Parvulastra exigua density}

Parvulastra exigua densities averaged $1.05 \pm 0.26$ and $2.9 \pm 0.59$ ind. $\mathrm{m}^{-2}$ in 1972 and 1973, but rose dramatically from 1975, peaking at $172.4 \pm 48.5$ ind. $\mathrm{m}^{-2}$ in 1980. Densities then declined and stabilised between 1990 and 2007, averaging between $10.4 \pm 0.2$ and $2 \pm$ 0.8 ind. $\mathrm{m}^{-2}$ (Fig. 1). Densities were always greatest in sediments occupied by the eelgrass Zostera capensis and increased from the high-water to the low-water mark (Fig. 2).

\section{Field experiments}

Benthic chl a concentrations (Fig. 3A) were significantly and negatively influenced by Parvulastra exigua density (Table $1, F_{3,23}=38.5, \mathrm{p}<0.0001$ ) and the interaction between $P$. exigua density and time $\left(F_{3,23}=8.0, \mathrm{p}<0.002\right)$, but not by time alone $\left(F_{1,23}=\right.$ $4.09, \mathrm{p}=0.06)$. After $1 \mathrm{mo}$, chl a concentrations did not differ between the control and $\mathrm{N}$ treatments (post hoc: $\mathrm{p}=0.98$ ), or between the $2 \mathrm{~N}$ and $4 \mathrm{~N}$ treatments (post hoc: $\mathrm{p}=0.54$ ), but were significantly greater in the control and $\mathrm{N}$ treatments than in the $2 \mathrm{~N}$ and $4 \mathrm{~N}$ treatments. After $2 \mathrm{mo}$, chl a levels were significantly greater in the controls relative to the treatments, with levels in the treatments not being statistically 


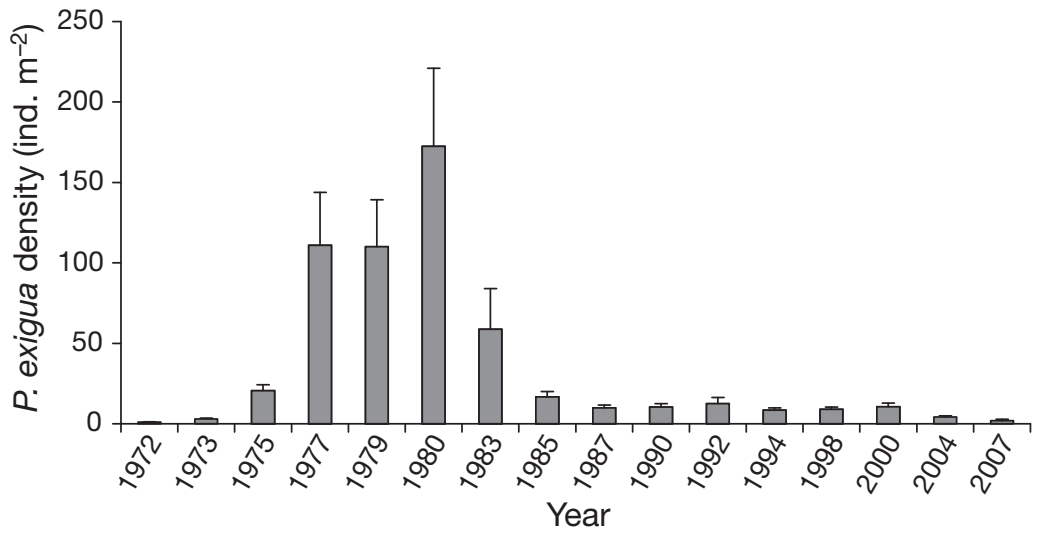

Fig. 1. Parvulastra exigua. Temporal variation in density in Langebaan Lagoon from 1972 to 2007, showing a population outbreak between 1975 and 1985 . Error bars: + $1 \mathrm{SE}$

different. Chl a concentrations declined linearly and were negatively correlated with density of $P$. exigua after both 1 mo $(\mathrm{R}=-0.93, \mathrm{p}<0.0001)$ and $2 \mathrm{mo}(\mathrm{R}=$ $-0.91, \mathrm{p}<0.0001$ ).

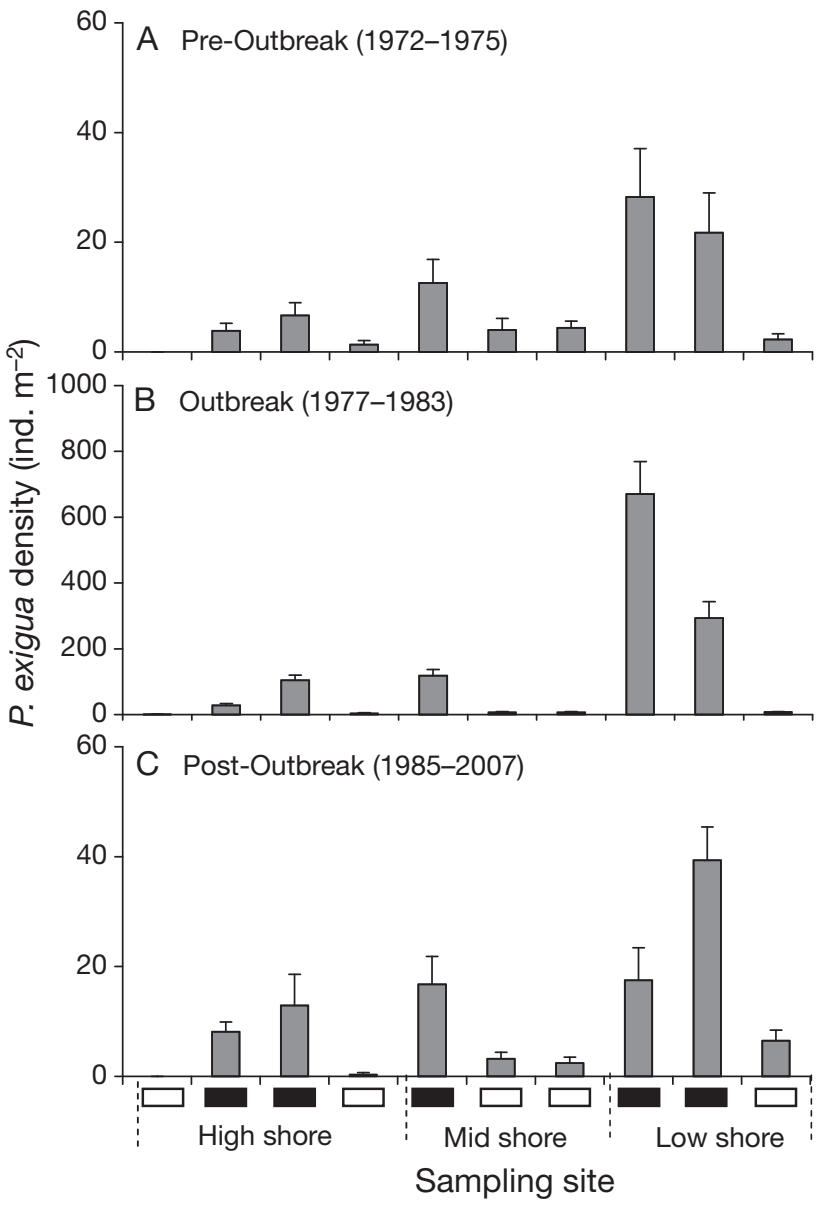

Fig. 2. Parvulastra exigua. Variation in density in Langebaan Lagoon (A) prior to, (B) during, and (C) after its outbreak, in zones with ( $\square$ ) or without $(\square)$ the eelgrass Zostera marina. Note the different scale of the $y$-axis in (B). Error bars: $+1 \mathrm{SE}$
Bacterial density (Fig. 3B) was significantly and positively affected by Parvulastra exigua density, time and by the interaction between these variables (Table 1) p $<0.0001$ for all). After $1 \mathrm{mo}$, bacterial density was statistically lower in the controls than in all other treatments $(\mathrm{p}<0.05)$, and was greatest in the $2 \mathrm{~N}$ and $4 \mathrm{~N}$ treatments $(\mathrm{p}<0.05)$, which did not differ between each other $(\mathrm{p}=$ 0.9). After $2 \mathrm{mo}$, bacterial density again rose as the density of $P$. exigua increased, although the control and $\mathrm{N}$ treatments did not differ significantly ( $p=0.33$ ). In contrast to the negative response of benthic chl a concentrations to $P$. exigua density, bacterial density was positively correlated with density of $P$. exigua after both 1 and 2 mo ( 1 mo: $\mathrm{R}=0.84, \mathrm{p}<0.0001 ; 2$ mo: $\mathrm{R}=$ 0.93, $\mathrm{p}<0.0001)$.

ANOSIM ( $p=0.35)$ indicated that Parvulastra exigua density had no effect on macrofaunal community structure. The MDS ordination and dendrogram (Fig. 4) suggested that macrofauna in the $2 \mathrm{~N}$ treat-
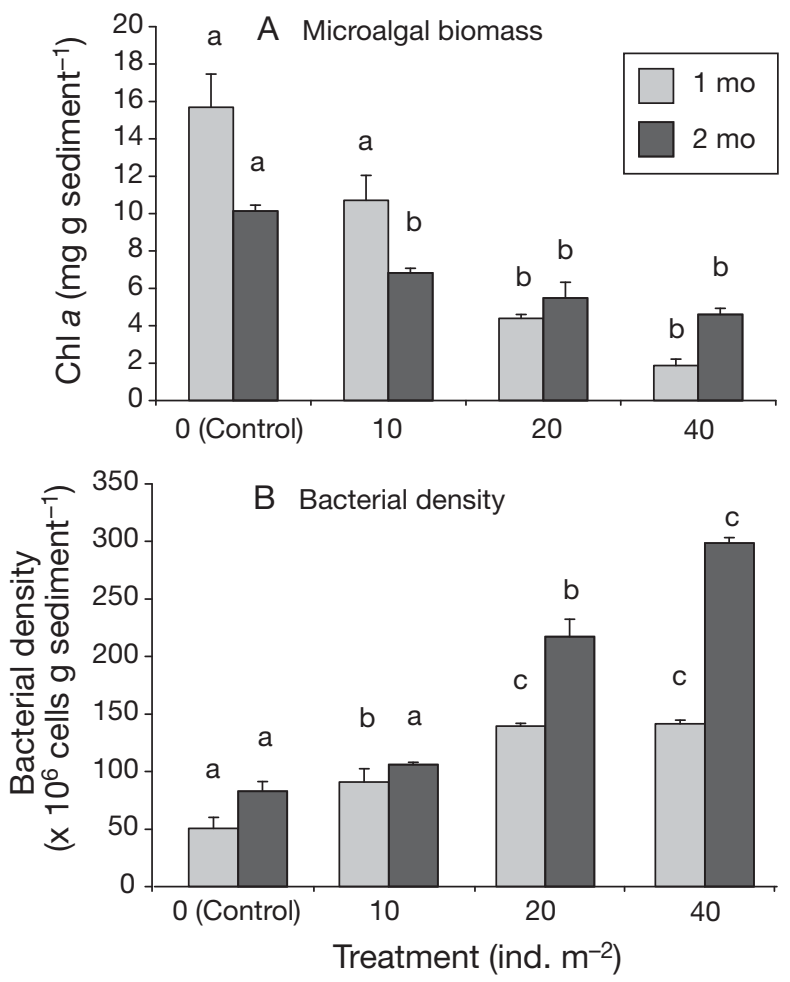

Fig. 3. Parvulastra exigua. Variations in (A) microalgal biomass, and (B) bacterial density after 1 and 2 mo at 4 densities: zero (control), natural density $\left(\mathrm{N}=10\right.$ ind. $\mathrm{m}^{-2}, 2 \mathrm{~N}=20$ ind. $\mathrm{m}^{-2}$, and $4 \mathrm{~N}=40$ ind. $\mathrm{m}^{-2}$ ). Shared letters above bars indicate an absence of significant differences among densities within each time period $(p>0.05)$. Error bars: $+1 \mathrm{SE}$ 
Table 1. Parvulastra exigua. Summary statistics of 2-way ANOVA testing effects of density, time and interaction on sediment chl $a$ and bacterial concentrations

\begin{tabular}{|lccrc|}
\hline Dependant variable & Source variable & df & $F$ & Significance \\
\hline Chl a & Time & 1 & 4.09 & 0.06 \\
& Density & 3 & 38.54 & $\mathrm{p}<0.0001$ \\
& Time $\times$ Density & 3 & 8.05 & 0.002 \\
Bacterial density & Time & 1 & 139.29 & $\mathrm{p}<0.0001$ \\
& Density & 3 & 139.79 & $\mathrm{p}<0.0001$ \\
& Time $\times$ Density & 3 & 28.17 & $\mathrm{p}<0.0001$ \\
\hline
\end{tabular}

Biomass and total density of macrofauna ( $p>0.05$ for both) did not differ significantly with density of Parvulastra exigua, despite apparent trends of declining biomass and density with increasing $P$. exigua density (Fig. 5). Species richness of macrofauna was also unrelated to density of $P$. exigua (Fig. 6A). Shannon-Wiener $\left(F_{3,11}=4.3\right.$, $\mathrm{p}=0.043)$ and Fischer's $\alpha$ diversity $\left(F_{3,11}=5.2, \mathrm{p}=0.028\right)$ indices for macrofauna did, however, differ significantly ments might be different to all others, as replicates from this treatment formed a spatially discrete cluster. However, pairwise testing indicated that this $2 \mathrm{~N}$ treatment was not statistically discernible from other treatments ( $p>0.05)$. Despite this, the polychaete and gastropod that contributed most to dissimilarity in treatments were always more abundant in the absence of $P$. exigua than in treatments containing it.

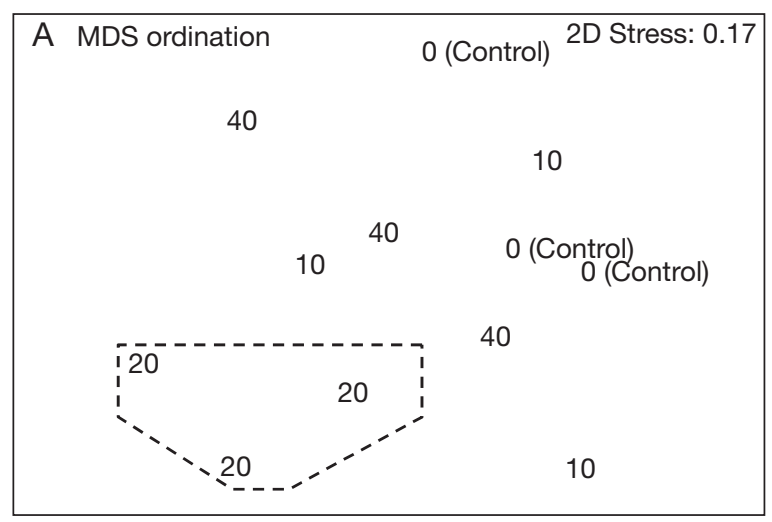

B Dendrogram

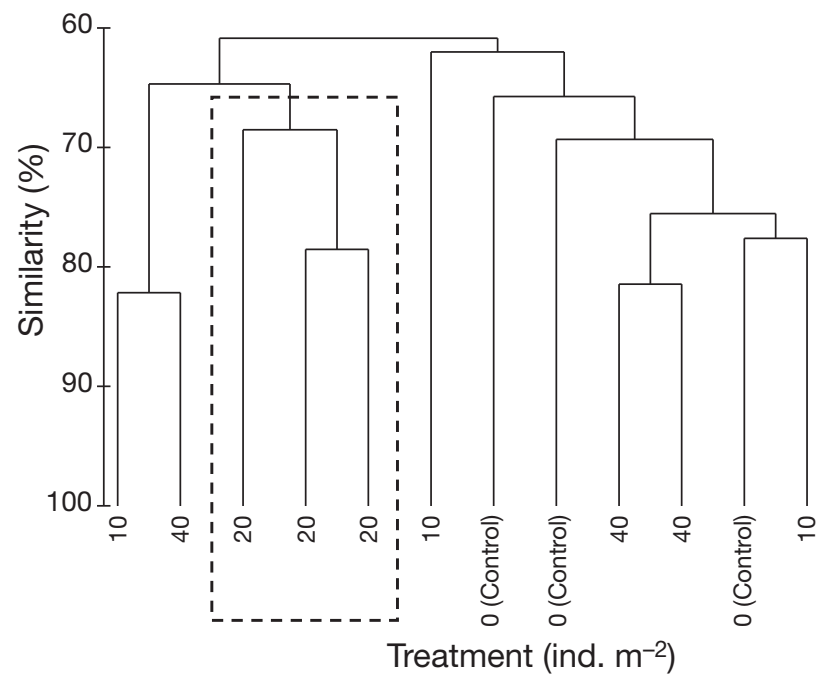

Fig. 4. Parvulastra exigua. MDS ordination (A) and dendrogram (B) showing spatial variation in macrofaunal community structure among the 4 density treatments among treatments, and showed unimodal humped responses to density of $P$. exigua (Fig. 6B,C ; ShannonWiener: $\mathrm{R}^{2}=0.56, \mathrm{p}=0.024 ; \alpha$ diversity: $\mathrm{R}^{2}=0.53, \mathrm{p}=$ 0.039). K-dominance curves (Fig. 7) further indicated that abundance of macrofauna was more evenly distributed in the $2 \mathrm{~N}$ treatment, followed by the $4 \mathrm{~N}, \mathrm{~N}$ and control treatments, indicating a positive influence of intermediate densities of $P$. exigua on macrofaunal diversity.

Simper indicated significant effects of Parvulastra exigua density on macrofaunal community composition (Table 2). The control and $\mathrm{N}$ treatments were dominated by the gastropod Protomella capensis and the polychaete Orbinia angrapequensis, which cumulatively contributed 90 and $93 \%$ to community structure in these treatments respectively. Macrofaunal communities in the $2 \mathrm{~N}$ treatment were more diverse, with the

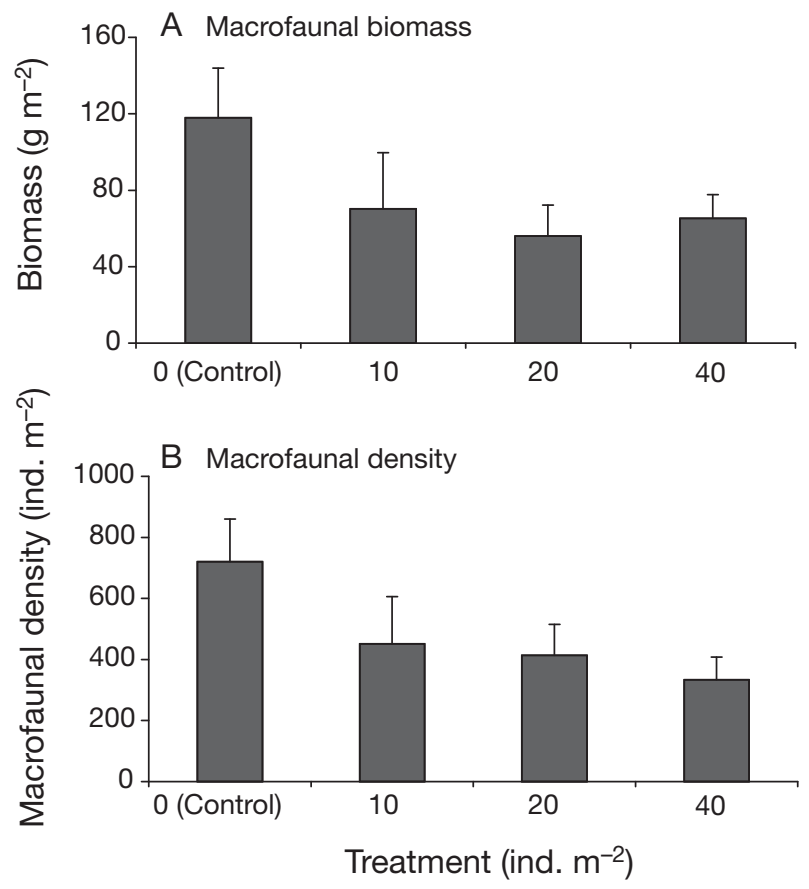

Fig. 5. Parvulastra exigua. Variations in (A) biomass and (B) density of macrofauna among the 4 density treatments. Error bars: + $1 \mathrm{SE}$ 
polychaetes Euclymene lumbricoides and O. angrapequensis, the crabs Hymenosoma orbiculare and Paratylodiplax edwardsii, together with the gastropods P. capensis and Nassarius spp., contributing $93 \%$ to community structure in this treatment. $P$. capensis and $O$. angrapequensis, together with $H$. orbiculare domi-
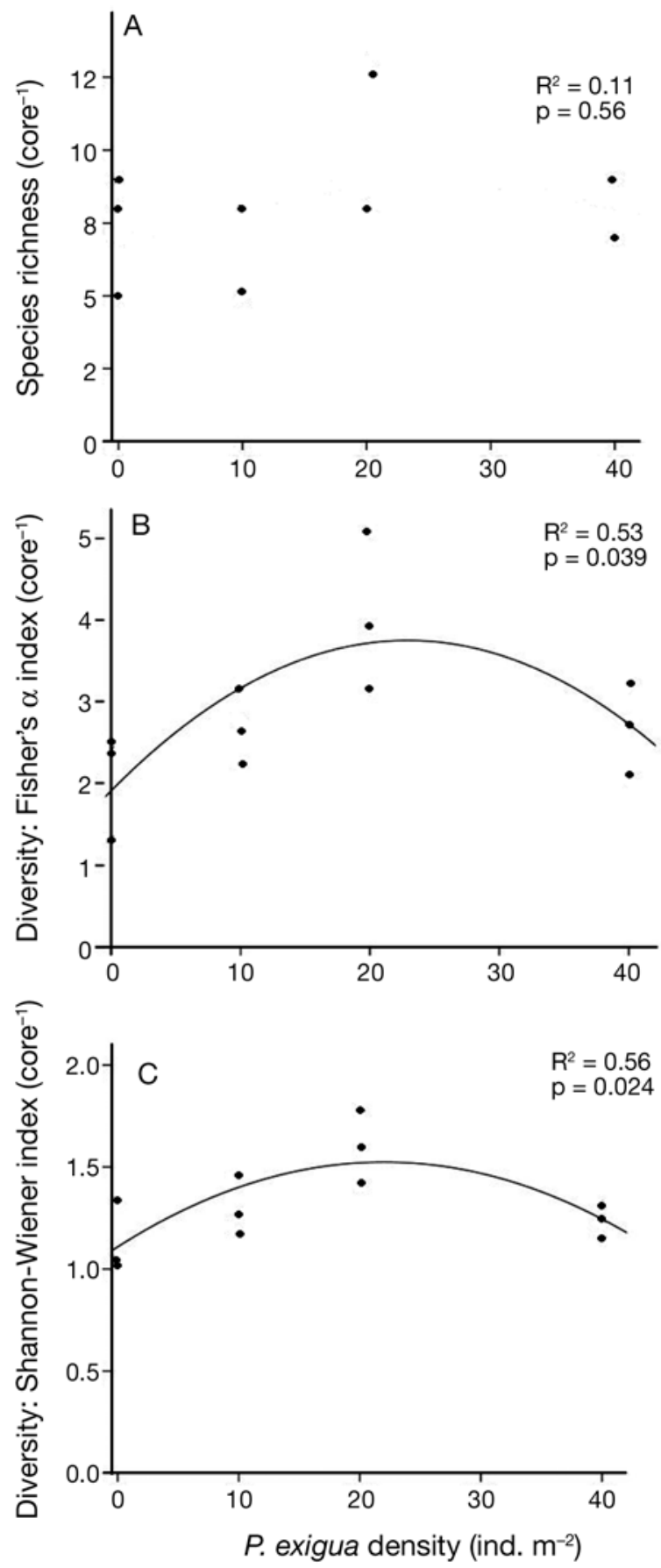

Fig. 6. Parvulastra exigua. Relationships between density and (A) species richness, (B) Fisher $\alpha$ diversity and (C) ShannonWiener diversity. Quadratic models were applied in cases where the relationships were significant

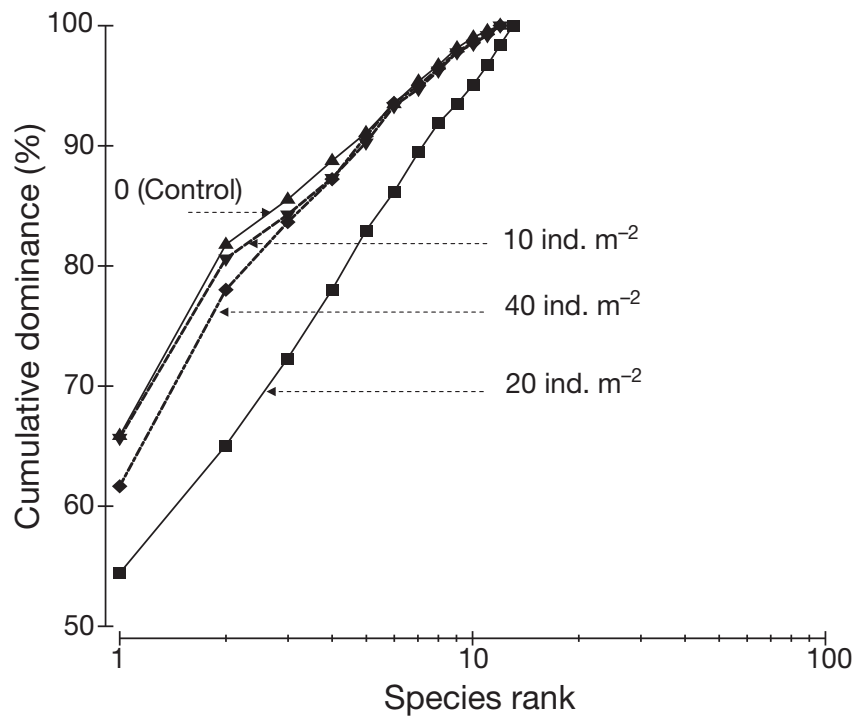

Fig. 7. Parvulastra exigua. Cumulative dominance curves showing difference in species dominance of macrofaunal assemblages among the 4 density treatments. Mean species abundances per treatment were used for the analysis

nated the $4 \mathrm{~N}$ treatment, cumulatively contributing $92 \%$ to community structure. The evenness and numbers of species contributing to the $2 \mathrm{~N}$ treatment again suggest a positive effect of intermediate densities of $P$. exigua on macrofaunal diversity.

\section{DISCUSSION}

At the start of our monitoring in 1972, Parvulastra exigua was present in Langebaan Lagoon but scarce. It seems that this state extended back to at least the 1950s, as Day (1959) listed this species as being present at Klein Oesterwal but insufficiently abundant to be recorded in transects documenting the prevalent species. Between 1977 and 1980, however, densities of $P$. exigua rose almost 200-fold, and followed immediately after a period of dredging and blasting to establish a harbour in the adjacent Saldanha Bay in 1976. This increased siltation in the lagoon and was associated with a collapse in eelgrass beds (Angel et al. 2006). With the decay of these beds, with which P. exigua is strongly associated (Fig. 2), a rich detrital pool was generated, which we surmise increased food availability for the microphagous $P$. exigua. Alternatively, dredging may have increase nutrient loads and microfloral levels (Riemann \& Hoffmann 1991), perhaps indirectly contributing to the outbreak in P. exigua.

Quantification of the effects of Parvulastra exigua on soft-sediment community structure after the outbreak 
Table 2. Parvulastra exigua. Macrofaunal species that contributed most to community structure in each of 4 treatments, as identified by SIMPER. Upper limit of species contributions (cumulative) was set at $90 \%$. Cum. cont. = Cumulative contribution

\begin{tabular}{|c|c|c|c|c|}
\hline $\begin{array}{l}\text { Treatment } \\
\text { (ind. } \mathrm{m}^{-2} \text { ) }\end{array}$ & $\begin{array}{l}\text { Species } \\
\text { (Group) }\end{array}$ & $\begin{array}{l}\text { Abundance } \\
\qquad\left(\mathrm{m}^{-2}\right)\end{array}$ & $\begin{array}{c}\text { Similarity } \\
(\%)\end{array}$ & $\begin{array}{c}\text { Cum. cont. } \\
(\%)\end{array}$ \\
\hline \multirow[t]{2}{*}{0 (Control) } & $\begin{array}{l}\text { Protomella capensis } \\
\text { (Gastropoda) }\end{array}$ & 47 & 51.54 & 77.75 \\
\hline & $\begin{array}{l}\text { Orbinia angrapequensis } \\
\text { (Polychaeta) }\end{array}$ & 11.3 & 10.15 & 93.06 \\
\hline \multirow[t]{2}{*}{10} & $\begin{array}{l}\text { Protomella capensis } \\
\text { (Gastropoda) }\end{array}$ & 29.3 & 32 & 77.4 \\
\hline & $\begin{array}{l}\text { Orbinia angrapequensis } \\
\text { (Polychaeta) }\end{array}$ & 6.6 & 5.91 & 90.86 \\
\hline \multirow[t]{6}{*}{20} & $\begin{array}{l}\text { Protomella capensis } \\
\text { (Gastropoda) }\end{array}$ & 22.3 & 32.7 & 55.8 \\
\hline & $\begin{array}{l}\text { Hymenosoma orbiculare } \\
\text { (Brachyura) }\end{array}$ & 4.3 & 8.2 & 69.8 \\
\hline & $\begin{array}{l}\text { Euclymene lumbricoides } \\
\text { (Polychaeta) }\end{array}$ & 2.3 & 4.6 & 77.7 \\
\hline & $\begin{array}{l}\text { Orbinia angrapequensis } \\
\text { (Polychaeta) }\end{array}$ & 2 & 3.5 & 83.7 \\
\hline & $\begin{array}{l}\text { Paratylodiplax edwardsii } \\
\text { (Brachyura) }\end{array}$ & 3 & 3.3 & 89.4 \\
\hline & $\begin{array}{l}\text { Nassarius spp. } \\
\text { (Gastropoda) }\end{array}$ & 1 & 2.5 & 93.7 \\
\hline \multirow[t]{3}{*}{40} & $\begin{array}{l}\text { Protomella capensis } \\
\text { (Mollusca: Gastropoda) }\end{array}$ & 29 & 51.3 & 73.2 \\
\hline & $\begin{array}{l}\text { Orbinia angrapequensis } \\
\text { (Polychaeta) }\end{array}$ & 7.6 & 10.7 & 88.5 \\
\hline & $\begin{array}{l}\text { Hymenosoma orbiculare } \\
\text { (Brachyura) }\end{array}$ & 1.6 & 2.8 & 92.6 \\
\hline
\end{tabular}

The positive effect of Parvulastra exigua on bacterial density is somewhat surprising, as grazing and bioturbation by this species would have been predicted to act in concert to reduced bacterial levels. Hargrave (1970) also demonstrated positive effects of the amphipod Hyalella azteca on bacterial respiration even at densities 4 times greater than those observed in the field, giving way to negative effects at greater amphipod densities, while positive and negative effects of grazing by heterotrophic nanoflagellates on bacteria have been reported in a pelagic lake environment (Gurung et al. 2000).

There are different mechanisms by which Parvulastra exigua may stimulate bacterial growth. (1) Browsing may positively affect bacteria by 'cropping' older cells, making way for new microbial cells. (2) Bacteria may be added to faeces in the gut, or after defacation, thereby stimulating bacterial growth on sediment (Hargrave 1970) and references cited therein. (3) Excretion by $P$. exigua, or the mucous web it produces during feeding (Branch \& Branch 1980), may add to the carbon and nitrogen content of the sediment thereby stimulating bacterial proliferation.

The differences in effects of Parvu-

revealed significant and novel findings. Firstly, grazing by $P$. exigua exerted a strong negative effect on microalgae in a density-dependant manner, but enhanced levels of bacteria. Such contrasting effects on microalgae and bacteria have also been reported for another South African soft-sediment grazer, the estuarine gastropod Assiminea globulus, which is common in the upper shore of Langebaan Lagoon (Pillay et al. 2009).

Jackson et al. (2009) demonstrated that grazing by Parvulastra exigua similarly reduces microalgae on Australian rocky shores, with each starfish being able to graze up to $60 \%$ of microalgae from the feeding area in a single feeding episode. Grazer-induced reductions in microalgae in soft sediments have also been reported by Morrisey (1988) for the gastropod Hydrobia ulvae and the amphipod Corophium arenarium and by Uthicke (1999) for the holothurians Holothuria (Halodeima) atra and Stichopus chloronotus. Although other studies in soft sediments have reported stimulation of microalgae at low grazer densities but inhibition at high densities (Hargrave 1970, Fenchel \& Kofoed 1976), we found only negative effects. lastra exigua on microalgae versus bacteria are probably linked to the relative regeneration times and nutritional value of these food sources. Bacteria have been viewed as a minor dietary component of deposit-feeding macrofauna, an idea affirmed by Levinton \& Bianchi (1981), who experimentally showed that grazing by the intertidal gastropod Hydrobia totteni negatively affects diatoms and blue-green algae, but not bacteria. In addition, the growth rate of $H$. totteni was not influenced by bacterial density, even when these microbes reached appreciable densities in sediments. Levinton \& Bianchi (1981) further speculated that $H$. totteni could survive entirely on a diet of microalgae and other non-living detritus. Regeneration time would also be an important factor affecting responses of bacteria and microalgae to grazing by $P$. exigua. Bacteria have faster turnover rates than microalgae, dividing as much as 1 to 6 times d $^{-1}$ (Hayes 1964), suggesting that they can sustain greater grazing pressure than microalgae. It is also possible that rapid cell division allows bacteria to respond faster to alterations in the physico-chemical environment induced by grazers (Hargrave 1970). 
Parvulastra exigua also displayed significant effects on benthic macrofauna. While ANOSIM was unable to identify statistically significant effects of $P$. exigua on macrofaunal community structure, graphical evidence from clustering and ordination indicated that communities were structurally different at intermediate densities of $P$. exigua. Additional evidence for this arose from cumulative dominance plots and SIMPER analysis, which both indicated greater diversity and reduced dominance in macrofaunal assemblages associated with intermediate densities of $P$. exigua. Furthermore, diversity of macrofauna (Shannon-Wiener, Fischer's $\alpha$ index) displayed a humped unimodal response to increasing densities of $P$. exigua, increasing up to intermediate densities of $P$. exigua, and then declining.

Widdicombe \& Austen (1998) showed that the combined effects of bioturbation and non-selective grazing by the heart urchin Brissopsis lyrifera can lead to enhanced infaunal diversity at intermediate densities. In a separate investigation, Widdicombe et al. (2000) tested the effects of 4 different types of bioturbators, viz. the heart urchin B. lyrifera, the bivalves Nuculoma tenuis and Abra alba, and the burrowing decapod $\mathrm{Ca}$ locaris macandreae on community structure. N. tenuis and $B$. lyrifera promoted infaunal diversity at intermediate densities, but this pattern was not apparent for A. alba and C. macandreae with the differences in specific effects being ascribed to differences in feeding type.

A unimodal pattern of species diversity along a gradient of increasing disturbance is predicted by the intermediate-disturbance hypothesis, and is frequently used to explain the responses of species to physical and biological disturbances (Paine \& Vadas 1969, Horn 1975, Connell 1978). This hypothesis proposes that species diversity will be reduced at low levels of disturbance, where dominant species prevent the establishment of sub-dominants by competitive exclusion, and at high levels of disturbance, where species with slow colonisation rates are selected against. At intermediate levels of disturbance, however, the disturbance reduces the competitive edge held by dominants, allowing for the establishment of subdominants.

Our data indicated that all treatments other than the intermediate Parvulastra exigua density treatments were dominated by 2 taxa, viz. the gastropod Protomella capensis and the polychaete Orbinia angrapequensis, which together contributed between 88 and $93 \%$ to community structure in these treatments. At intermediate densities of $P$. exigua, these species were less dominant, with 4 other taxa contributing roughly $30 \%$ to community structure. $K$-dominance curves also pointed to reduced dominance in macrofaunal communities at intermediate densities of $P$. exigua. Based on the evidence, it seems that $P$. exigua enhances macro- faunal diversity at intermediate densities, possibly because the combined effects of non-selective grazing and bioturbation act as disturbances, thereby preventing competitive exclusion of sub-dominant species. There are a few studies showing that competition and competitive exclusion may influence soft-sediment communities, but on the whole, these processes have not been as emphatically demonstrated in softsediment ecosystems as they have on rocky shores (Peterson 1979, Wilson 1991, Seitz 1998, Little 2000). This is partly due to the 3- and 2-dimensional natures of these respective ecosystems, allowing soft-sediment organisms to partition space vertically, thereby reducing the chances of competitive interactions. In addition, evidence for food limitation in soft sediments is rare, so competition for food is less likely (Seitz 1998).

The lack of convincing and consistent demonstrations of competitive exclusions in soft sediments raises an alternate mechanism by which Parvulastra exigua promotes co-existence of macrofaunal species at intermediate densities. In our experiments, we demonstrated a promotive effect of $P$. exigua on bacterial abundance, which likely enhances microbial biofilm production and coverage at the sediment surface. Biofilms are complex matrices of bacteria and other microbes co-existing in extracellular polymeric secretions (Underwood \& Paterson 1995), with their biochemical constituents acting as important cues for larval settlement, generally signalling better survival opportunities in the form of greater food availability and substrate stability (Pillay et al. 2007). Importantly, biofilms have also been shown to enhance richness and diversity of juvenile assemblages recruiting into adult communities on soft sediments (Pillay et al. 2007). The apparent effect of $P$. exigua in reducing competitive exclusion can therefore alternatively be explained by its promotive effects on bacteria, biofilms and recruit diversity. At low $P$. exigua density, diversity of recruits may be limited by low biofilm coverage, but enhanced as density of $P$. exigua and biofilm coverage increase. As $P$. exigua exceeds intermediate levels, its grazing may outweigh any promotive effects of biofilms, selecting against species with slow recovery times.

Our results revealed novel effects of the starfish Parvulastra exigua on community structure in intertidal sandflats and concur with the notion of Jackson et al. (2009) that grazing by this echinoderm may be an underestimated force in intertidal systems. Its promotive effects on bacteria and macrofauna were unanticipated, but importantly suggest a need for caution when using studies from soft sediments as support for the intermediate disturbance hypothesis without a full appreciation of the promotive effects of the target organism. 


\section{LITERATURE CITED}

Andersen TJ (2001) Seasonal variation in erodibility of two temperate, microtidal mudflats. Estuar Coast Shelf Sci 53: $1-12$

Andersen TJ, Jensen KT, Lund-Hansen L, Mouritsen KN, Pejrup M (2002) Enhanced erodibility of fine-grained marine sediments by Hydrobia ulvae. J Sea Res 48:51-58

Anderson MJ (1999) Distinguishing direct from indirect effects of grazers in estuarine intertidal assemblages. J Exp Mar Biol Ecol 234:199-218

- Anderson MJ, Underwood AJ (1997) Effects of gastropod grazers on recruitment and succession of an estuarine assemblage: a multivariate and univariate approach. Oecologia 109:442-453

> Angel A, Branch GM, Wanless RM, Siebert T (2006) Causes of rarity and range restriction of an endangered, endemic limpet. J Exp Mar Biol Ecol 330:245-260

Branch GM, Branch ML (1980) Competition between Cellana tramoserica (Sowerby) (Gastropoda) and Patiriella exigua (Lamarck) (Asteroidea), and their influence on algal standing stocks. J Exp Mar Biol Ecol 48:35-49

Brodeur RD, Sugisaki H, Hunt GL (2002) Increases in jellyfish biomass in the Bering Sea: implications for the ecosystem. Mar Ecol Prog Ser 233:89-103

Brodie J, Fabricius K, De'ath G, Okaji K (2005) Are increased nutrient inputs responsible for more outbreaks of crownof-thorns starfish? An appraisal of the evidence. Mar Pollut Bull 51:266-278

Clarke RT, Gorley RN (2006) PRIMER v6: User Manual/Tutorial. PRIMER-E, Plymouth

> Connell JH (1978) Diversity in tropical rain forests and coral reefs. Science 199:1302-1310

Day JH (1959) The biology of Langebaan Lagoon: a study of the effect of shelter from wave action. Trans R Soc S Afr 35:475-547

- Elner RW, Vadas RL (1990) Inference in ecology: the sea urchin phenomenon in the northwestern Atlantic. Am Nat 136:108-125

Fenchel T, Kofoed LH (1976) Evidence for exploitative interspecific competition in mud snails (Hydrobiidae). Oikos $27: 367-376$

Flint RW, Goldman CR (1975) The effects of a benthic grazer on the primary productivity of the littoral zone of Lake Tahoe. Limnol Oceanogr 20:935-944

Gurung TB, Nakanishi M, Urabe J (2000) Seasonal and vertical difference in negative and positive effects of grazers on heterotrophic bacteria in Lake Biwa. Limnol Oceanogr 45:1689-1696

Hargrave BT (1970) The effects of a deposit-feeding amphipod on the metabolism of benthic microflora. Limnol Oceanogr 15:21-30

Hawkins SJ, Hartnoll RG (1983) Grazing of intertidal algae by marine invertebrates. Oceanogr Mar Biol Annu Rev 21: $195-282$

Hayes FR (1964) The mud-water interface. In: Barnes H (ed) Oceanogr Mar Biol Annu Rev 2:121-145

Horn HS (1975) Markovian properties of forest succession. In: Cody ML, Diamond JM (eds) Ecology and evolution of communities. Belknap Press, Cambridge, MA, p 196-211

$>$ Hunt JH, Ambrose WG Jr, Peterson CH (1987) Effects of the gastropod, Ilyanassa obsoleta (Say), and the bivalve, Mercenaria mercenaria (L.), on larval settlement and juvenile recruitment of infauna. J Exp Mar Biol Ecol 108:229-240

> Jackson AC, Murphy RJ, Underwood AJ (2009) Patiriella exigua: grazing by a starfish in an overgrazed intertidal system. Mar Ecol Prog Ser 376:153-163
Kelaher BP, Levinton JS, Hoch JM (2003) Foraging by the mud snail Ilyanassa obsoleta (Say) modulates spatial variation in benthic community structure. J Exp Mar Biol Ecol 292:139-157

Levinton JS, Bianchi T (1981) Nutrition and food limitation of deposit-feeders I. The role of microbial organisms in the growth of mud snails (Hydrobiidae). J Mar Res 39: 531-545

Levinton JS, Stewart S (1982) Marine succession: the effect of two deposit-feeding gastropod species on the population growth of Paranais litoralis Muller 1784 (Oligochaeta). J Exp Mar Biol Ecol 59:231-241

Little C (2000) The biology and soft shores and estuaries. Oxford University Press, New York

> Lohrer AM, Thrush SF, Gibbs MM (2004) Bioturbators enhance ecosystem function through complex biogeochemical interactions. Nature 431:1092-1095

Lorenzen CJ (1967) Determination of chlorophyll and phaeopigments: spectrophotometric equations. Limnol Oceanogr 12:243-246

McClintock JB, Lawrence JM (1985) Characteristics of foraging in the soft-bottom benthic starfish Luidia clathrata (Echinodermata: Asteroidea): prey selectivity, switching behavior, functional responses and movement patterns. Oecologia 66:291-298

Moran PJ, Bradbury RH, Reichelt RE (1988) Distribution of recent outbreaks of the crown-of-thorns starfish (Acanthaster planci) along the Great Barrier Reef: 1985-1986. Coral Reefs 7:125-137

> Morrisey DY (1988) Differences in effects of grazing by deposit-feeders Hydrobia ulvae (Pennant) (Gastropoda: Prosobranchia) and Corophium arenarium (Crawford) (Amphipoda) on sediment microalgal populations. II. Quantitative effects. J Exp Mar Biol Ecol 118:43-53

Orvain F, Sauriau PG, Sygut A, Joassard L, Le Hir P (2004) Interacting effects of Hydrobia ulvae bioturbation and microphytobenthos on the erodibility of mudflat sediments. Mar Ecol Prog Ser 278:205-223

> Paine RT (1974) Intertidal community structure: experimental studies on the relationship between a dominant competitor and its principal predator. Oecologia 15: 93-120

Paine RT, Vadas RL (1969) The effects of grazing by sea urchins, Strongylocentrotus spp., on benthic algal populations. Limnol Oceanogr 14:710-719

Peterson CH (1979) Predation, competitive exclusion, and diversity in the soft sediment benthic communities of estuaries and lagoons. In: Livingston RJ (ed) Ecological processes in coastal and marine systems. Plenum Press, New York, p 233-264

Pillay D, Branch GM, Forbes AT (2007) Effects of Callianassa kraussi on microbial biofilms and recruitment of macrofauna: a novel hypothesis for adult-juvenile interactions. Mar Ecol Prog Ser 347:1-14

Pillay D, Branch GM, Steyn A (2009) Complex effects of the gastropod Assiminea globulus on benthic community structure in a marine dominated-lagoon. J Exp Mar Biol Ecol 380:47-52

Purcell JE, Uye S, Lo WT (2007) Anthropogenic causes of jellyfish blooms and their direct consequences for humans: a review. Mar Ecol Prog Ser 350:153-174

Riemann B, Hoffmann E (1991) Ecological consequences of dredging and bottom trawling in the Limfjord, Denmark. Mar Ecol Prog Ser 69:171-178

Scheibling RE (1980) The microphagous feeding behavior of Oreaster reticulatus (Echinodermata: Asteoridea). Mar Freshw Behav Physiol 7:225-231 
Seitz RD (1998) Incorporation of soft-sediment systems into a model of marine benthic community regulation. Mar Freshw Res 49:817-826

Silliman BR, Bertness MD (2002) A trophic cascade regulates salt marsh production. Proc Natl Acad Sci USA 99: 10500-10505

Underwood GJC, Paterson DM (1995) The measurement of microbial carbohydrate exopolymers from intertidal sediments. Limnol Oceanogr 40:1243-1253

Uthicke S (1999) Sediment bioturbation and impact of feeding activity of Holothuria (Halodeima) atra and Stichopus chloronotus, two sediment feeding holothurians, at Lizard Island, Great Barrier Reef. Bull Mar Sci 64:129-141

Uthicke S, Schaffelke B, Byrne M (2009) A boom-bust phylum? Ecological and evolutionary consequences of

Editorial responsibility: James McClintock,

Birmingham, Alabama, USA density variations in echinoderms. Ecol Monogr 79: $3-24$

Widdicombe S, Austen MC (1998) Experimental evidence for the role of Brissopsis lyrifera (Forbes, 1841) as a critical species in the maintenance of benthic diversity and the modification of sediment chemistry. J Exp Mar Biol Ecol 228: 241-255

Widdicombe S, Austen MC, Kendall MA, Warwick RM, Jones MB (2000) Bioturbation as a mechanism for setting and maintaining levels of diversity in subtidal macrobenthic communities. Hydrobiologia 440:369-377

Wilson WH (1990) Competition and predation in marine softsediment communities. Annu Rev Ecol Syst 21:221-241

Xian WB, Kang B, Liu R (2005) Jellyfish blooms in the Yangtze Estuary. Science 307:41

Submitted: June 19, 2009; Accepted: August 26, 2009

Proofs received from author(s): November 24, 2009 